\title{
Threshold Limits of Soil in Relation to Various Soil Functions and Crop Productivity
}

\section{Atul Bhagawan Pawar*, Chiranjeev Kumawat, Anil Kumar Verma, Ravi Kumar Meena, Md. BasitRaza, Ajin S. Anil and V.K. Trivedi}

\author{
Division of Soil Science and Agricultural Chemistry, Indian Agricultural Research Institute, \\ New Delhi - 110012, India \\ *Corresponding author
}

\section{A B S T R A C T}

Soil Organic Carbon (SOC) is the key parameter which drives various soil functions. It provides integrative benefits in protecting the environment and sustaining agriculture. Some scientists have described SOC as a 'universal keystone indicator' in soil fertility management, making it an appropriate tool for managing heterogeneity with respect to soil fertility among farmer fields. Too much or too little SOC can equally be an environmental threat leading to pollution

\section{Keywords}

Threshold, Musinguziet, Gangetic, Biomass, Charcoal.

Article Info

Accepted: 25 April 2017 Available Online: 10 May 2017 or loss of biodiversity. The establishment of SOC threshold is one of the measures that can be employed to overcome this problem. However, only few studies have been attempted to discuss minimum or maximum threshold values of SOC above or below which the beneficial effects of SOC is diminished. On the other hand a minimum critical value of $1.2 \%$ SOC in ferralsols of Uganda. An increase in microbial activity was found, indicated by rise in various enzymatic activities within a range of 1.52-1.82\% SOC (Lopes et al., 2013). Similarly, a good correlation was found between SOC and available micronutrients. The influence of water potential and organic carbon on the sensitivity of soil to mechanical disturbance was showed. Their study showed that soils become more sensitive to mechanical damage when wetter and the most dramatic effect is observed for soils with $<1.5 \%$ organic carbon. A minimum critical value of $2 \%$ was shown above which there was significant increase in CEC. In spite of all past efforts it is difficult to establish a single minimum or maximum SOC threshold value that can be universally or regionally accepted. So this provides scope for development of method that can be used to predict SOC threshold considering all variables.

\section{Introduction}

\section{Soil organic matter (SOM)}

Soil organic matter in its broadest sense, encompasses all of the organic materials found in soils irrespective of its origin or state of decomposition. Included are living organic matter (plants, microbial biomass and faunal biomass), dissolved organic matter, 
particulate organic matter, humus and inert or highly carbonised organic matter (charcoal and charred organic materials). The functional definition of soil organic matter excludes organic materials larger than $2 \mathrm{~mm}$ in size (Baldock and Skjemstad, 1999).

\section{Soil organic carbon (SOC)}

Soil organic matter is made up of significant quantities of $\mathrm{C}, \mathrm{H}, \mathrm{O}, \mathrm{N}, \mathrm{P}$ and $\mathrm{S}$. Conversion factors can be applied to the level of soil organic carbon to provide an estimate of the level of soil organic matter based on the content of carbon in the soil organic matter. The general conversion factor is 1.72 , so the level of soil organic matter is $\approx 1.724 \mathrm{x}$ the soil organic carbon. However this conversion factor does vary depending on the origin and nature of the soil organic matter from 1.72 to 2.0 .

\section{Overview of principal functions of SOM in soils}

The functions of SOM can be broadly classified into three groups: biological, physical and chemical (Fig. 1). These groups are not static entities and dynamic interactions occur between these three major components. It is these interactions among the soil functions, that supports different requirements for optimal SOC levels for each function and the individual soil mineralogical characteristics that preclude a generic number for optimal SOM levels.

Soil quality is defined as the ability of the soil to function. It is the capacity of a specific kind of soil to function, within natural or managed ecosystem boundaries to sustain plant and animal production, maintain or enhance water and air quality and support human health and habitation (Karlen et al., 1997).

So several soil functions have been delineated for satisfying various management goals, and these functions have multiple indicators that describe the state of the soil.

Soil fertility is the ability of the soil to supply essential nutrients and water for supporting plant growth. SOC forms the core part of soil fertility. Thus, higher the amount of SOC, more fertile is the soil and more is the crop productivity. The improvement of SOC and soil fertility is fundamental for ensuring food security.

\section{Soil organic carbon threshold - Is it} needed?

Smith and Dumanski (1993) defined thresholds as critical levels above which a system responds significantly to stimuli. Pieri (1995) on the contrary defined thresholds considering the environmental aspect. He defined thresholds as values of certain variables above which a significant shift orrapid negative change takes place.

Too much or too little SOC can equally be an environment threat leading to pollution or loss of biodiversity. It is common to conclude that increasing soil organic carbon by applying organic materials is a good practice. However, the addition of excess inputs needs to be applied with caution as this can lead to soil nutrient imbalances of nitrogen or phosphorus, and can lead to pollution of surface and ground waters. Low SOC amount is also an environmental threat since low fertility results in low biomass yield. Such level can also result in significant fertilizer loss because of low buffer or retention capacity. Oades, Gillman and Uehara (1989) noted that applying extra levels of organic residues can lead to acidification due to nitrification. Application of extra amounts of carbon can also result in the crusting of soil surface, decreased hydraulic conductivity, and increased run-off (Haynes \& Naidu, 1998). The minimum and maximum SOC thresholds at which soils can support crop production 
while sustaining a friendly environment remain a less explored option.

\section{SOC threshold in relation to nutrient} cycling

Soil organic carbon is central to nutrient cycling and nutrient supply in most soils. Although industrial fertilisers have been a major source of nutrients for agricultural soils, the soil organic carbon, including the microbial component, still remains a major factor influencing pathways for plants to obtain the nutrients needed for growth.

The effects of organic manure and chemical fertilizer on total soil organic carbon (TC), microbial biomass C (MBC), bulk density (B.D) were studied under a wheat-maize cropping system in a long-term experiment, which was established in 1989 in the North China Plain. The experiment included seven treatments: (1) OM: application of organic manure; (2) $1 / 2 \mathrm{OMN}$ : application of $1 / 2$ organic manure + chemical fertilizer NPK; (3) NPK: balanced application of chemical fertilizer NPK; (4) NP: application of chemical fertilizer NP; (5) PK: application of chemical fertilizer PK; (6) NK: application of chemical fertilizer NK; and (7) CK: unfertilized control.

The treatment having only organic manure application gave maximum increase of total SOC and microbial biomass with minimal bulk density as compared to other treatments. The study showed a positive influence of organic manure in maintaining physical and biological properties of soil thus indirectly influencing nutrient cycling function. There is growing evidence that soil microbial attributes are potential early indicators of changes in soil quality because they are more sensitive than a soil's chemical and physical properties (Miller and Dick, 1995; Bandick and Dick, 1999; Kandeler et al., 1999;
Bending et al., 2004; Geisseler and Horwath, 2009; Peixoto et al., 2010). An interpretative framework for microbial biomass C (MBC), basal respiration, and the activity of soil enzymes cellulase, $\quad \beta$-glucosidase, arylsulfatase, and acid phosphatase was developed.

\section{Micronutrient availability}

SOM is an important source of nutrients for plants in general and crops in particular. Nitrogen, phosphorus and sulphur are considered macronutrients, essential micronutrients are iron, manganese, zinc, copper, boron, molybdenum, and chlorine and beneficial but not essential elements are silicon, vanadium, cobalt and nickel. Particular emphasis will be placed here on the role of carbon in regulating biochemical mineralization of micronutrients.

On the basis of the critical limits of DTPA extractable Fe, $\mathrm{Mn}, \mathrm{Zn}$ and Cui.e.4.5 mg, 2.5 $\mathrm{mg} 0.6 \mathrm{mg}, 0.2 \mathrm{mg}$ respectively, suggested by Lindsay and Norvell (1978), the corresponding critical limits of SOC was found out from the regression equations and are $0.52 \%, 0.48 \%, 0.71 \%$ and $0.54 \%$ respectively.

\section{SOC threshold in relation to soil physical stability}

\section{Soil structure and aggregate stability}

Soil structural stability refers to the resistance of soil to structural rearrangement of pores and particles when exposed to different stresses (e.g. cultivation, trampling/ compaction, and irrigation). It is well established that addition of SOM can not only reduce bulk density and increase water holding capacity, but also effectively increase soil aggregate stability. Ackerman \& Myers (1943) found, for soils under grass, strong 
correlation $(\mathrm{r}>0.95 ; \mathrm{p}<0.001)$ between the stability of aggregates $(\mathrm{d}>0.106 \mathrm{~mm})$ in water and soil organic carbon content and soil $\mathrm{N}$ content.

Angers and Carter (1996) noted that the amount of water-stable aggregates (WSA) was often associated with SOC content, and that particularly labile carbon was often positively related to macro-aggregate stability.

Kay and Angers (1999) reported that a minimum of $2 \%$ SOC was necessary to maintain structural stability and observed that if SOC content was between 1.2-1.5\%, stability declined rapidly.

\section{Bulk density}

The bulk density is the mass of dry soil per bulk volume of the soil. The mass of dry soil is determined by drying the soil to constant weight at $105^{\circ} \mathrm{C}$. Bulk density has a strong relationship with organic matter. Generally, the higher the level of organic matter, the lower the bulk density. Higher aggregate stability associated with higher levels of soil organic matter increases soil porosity which results in a lower bulk density.

However bulk density is also affected by other soil properties such as soil texture, clay mineral type, sodicity and exchangeable cations, and the presence of iron and aluminium oxides.

Land use history can also affect bulk density through cultivation, the time since cultivation and the amount of rain since the cultivation and compaction by stock or machinery. Despite these complications several relationships between bulk density and organic matter have been published which have been show in table. 2 .

\section{Soil organic carbon threshold in relation to filtering \& buffering}

\section{SOC threshold limits in relation to CEC}

Cation exchange capacity is the capacity of the soil to hold exchangeable cations. The negative charge that accounts for the CEC of soils has two major sources:

The clay or soil minerals which vary in the net negative charge which arises from the crystalline structure of clay or soil minerals.

Humus in soil organic matter - this has the complication that the net charge on the organic matter can be dependent on the soil $\mathrm{pH}$. This occurs because the net charge on the organic compounds responsible for the cation exchange capacity can be $\mathrm{pH}$ dependent and the ionic strength of the soil solution (Rengasamy and Churchman, 1999).

Generally the greater the degree of decomposition or humification of the organic matter the higher the CEC of the organic matter (Stevenson 1982).

\section{Soil organic carbon threshold in relation to crop productivity}

Studies to quantify the effects of soil organic matter on yield and productivity and the economic impacts are difficult to undertake because of the complexity of the effects of soil organic matter. Managing for soil organic matter remains a sound basis for maintaining soil in a good condition for optimising productivity and for maintaining the productive capacity of the soil in the long term. It is soil organic matter that provides much of the physio-chemical activity required by the soil to carry out the functions required for crop and pasture production. Soil organic carbon provides a source for the cycling of nutrients in the soil as well as providing a 
source of food for the microorganisms responsible for the recycling of nutrients. A soil with adequate soil organic carbon is always likely to be more productive and have the capacity to sustain productivity than a soil that is deficient in soil organic carbon. The most practical way to enhance soil quality is to promote the better management of soil carbon and soil organic matter.

Biswas et al., (2017) established critical limits for two soil orders i.e. entisol and alfisols collected from farmers' fields with long term rice-rice cropping system in sub-tropical India (fig.2). The critical limit of a soil quality indicator is the desirable range of its values required for normal functioning of soil and maintenance of its health for sustainable crop production. The relative yield (RY) of rice was defined as being 100 times the yield of a site divided by the yield of a site produced the maximum yield with adequate but not excessive amounts of all the inputs. Precisely, the regression lines were computed between the relative yields and value of SOC for assessing the critical limits. In the regression equation, relative yield, $(\mathrm{Y})=80$ and 40 were taken and the corresponding value of the indicator represented its upper and lower critical limits, respectively (Lopes et al., 2013). The values of key indicators that were higher than RY of $80 \%$ were considered as adequate, assuming that RY of $80 \%$ corresponds to the production of maximum economic efficiency (Lopes et al., 2013) as per the critical level concept of soil nutrients (Cate and Nelson, 1971). Values of key indicators corresponds to RY of 41 and $80 \%$ were classified as moderate, while the values corresponding to RY of $40 \%$ were classified as low (Lopes et al., 2013). By using this approach they delineated a critical range of SOC for both the soil orders; alfisols $(0.5 \%$ $0.77 \%)$ and entisols (1.03\%-1.16\%).

Table.1 Soil bulk density, total organic C, microbial biomass $\mathrm{C}$ after 18 years of different fertilization treatments (Gong et al.,2008)

\begin{tabular}{|c|c|c|c|}
\hline Treatments & Total C (g/kg) & $\begin{array}{c}\text { Bulk density } \\
\mathbf{g} / \mathbf{c m}^{\mathbf{3}}\end{array}$ & $\begin{array}{c}\text { Microbial biomass } \\
\text { (mg/kg) }\end{array}$ \\
\hline OM & 9.41 & 1.20 & 135.8 \\
\hline $1 / 2 \mathrm{OMN}$ & 7.16 & 1.26 & 98.7 \\
\hline NPK & 5.59 & 1.29 & 74.4 \\
\hline NP & 5.21 & 1.30 & 65.5 \\
\hline PK & 4.85 & 1.32 & 55.8 \\
\hline NK & 4.23 & 1.35 & 46.8 \\
\hline C & 3.92 & 1.40 & 41.7 \\
\hline
\end{tabular}


Table.2 SOC threshold limits in relation to bulk density

\begin{tabular}{|l|c|c|c|}
\hline \multicolumn{1}{|c|}{ RELATIONSHIP } & $\begin{array}{c}\text { ADDITIONAL } \\
\text { INFORMATION }\end{array}$ & SOC\% & REFERENCE \\
\hline $\begin{array}{l}\mathrm{D}_{\mathrm{b}} \text { (grass) }=1.37-0.76 \times \text { SOC\% } \\
\left(\boldsymbol{R}^{2}=0.69\right)\end{array}$ & $\begin{array}{c}\text { Grassland and } \\
\text { arable soils }\end{array}$ & $2 \%$ (Max.) & $\begin{array}{c}\text { Williams } \\
(1971)\end{array}$ \\
\hline $\begin{array}{l}\mathrm{D}_{\mathrm{b}}(\mathrm{g} \mathrm{cm}-3)=1.62 \times 0.134 \times \text { SOC\% } \\
\left(\boldsymbol{R}^{2}=0.99\right)\end{array}$ & Silty loam soil & -- & $\begin{array}{c}\text { Shiel and } \\
\text { Rimmer } \\
(1984)\end{array}$ \\
\hline $\begin{array}{l}\mathrm{D}_{\mathrm{b} \text { max }}=1.62 \times \mathrm{SOC}^{-0.079}\left(\boldsymbol{R}^{2}=\right. \\
0.90)\end{array}$ & $\begin{array}{c}\text { Podzolic and } \\
\text { Luvisolic soils in } \\
\text { Prince Edward } \\
\text { Island }\end{array}$ & $0.3-2.1 \%$ & Carter (1987) \\
\hline $\begin{array}{l}\mathrm{D}_{\mathrm{b}}=1.61-0.09 \times \mathrm{SOC} \% \\
\left(\boldsymbol{R}^{2}=0.977\right)\end{array}$ & $\begin{array}{c}\text { Sandy loam and } \\
\text { loamy sand soils }\end{array}$ & -- & Ekwue (1990) \\
\hline $\begin{array}{l}\mathrm{D}_{\mathrm{b}}=-0.102 \times(\mathrm{OM} \%)+2.07 \\
\left(\boldsymbol{R}^{2}=0.93\right)\end{array}$ & \begin{tabular}{c} 
Clay loam soil \\
\hline
\end{tabular} & -- & $\begin{array}{c}\text { Cannell et al. } \\
(1994)\end{array}$ \\
\hline
\end{tabular}

Fig.1 Functions of SOM by Baldock and Skjemstad, 1999

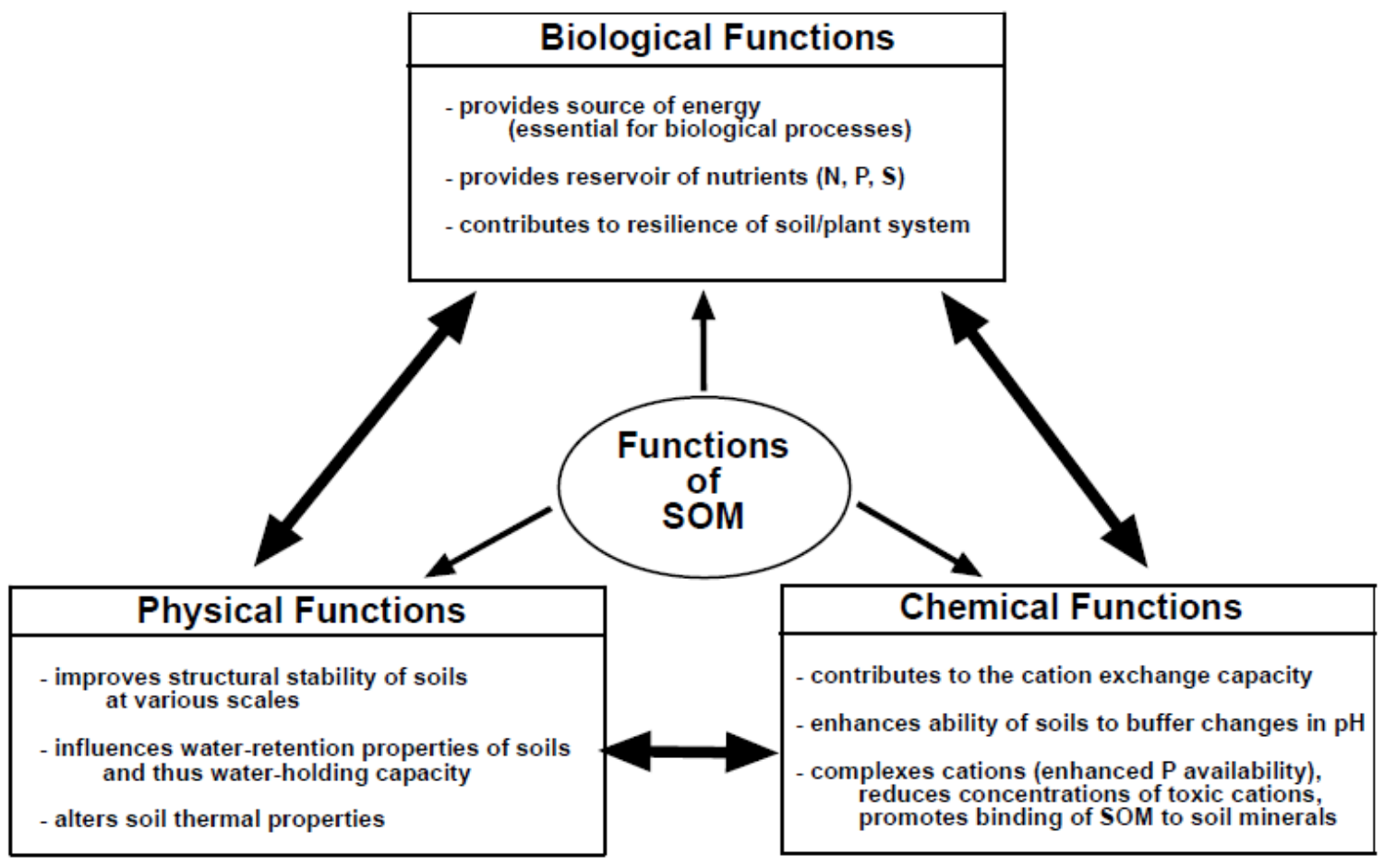


Fig.2 Critical limits of SOC in 2 soil orders in rice-rice cropping system in Indo-Gangetic plain a) Entisol, b) Alfisol
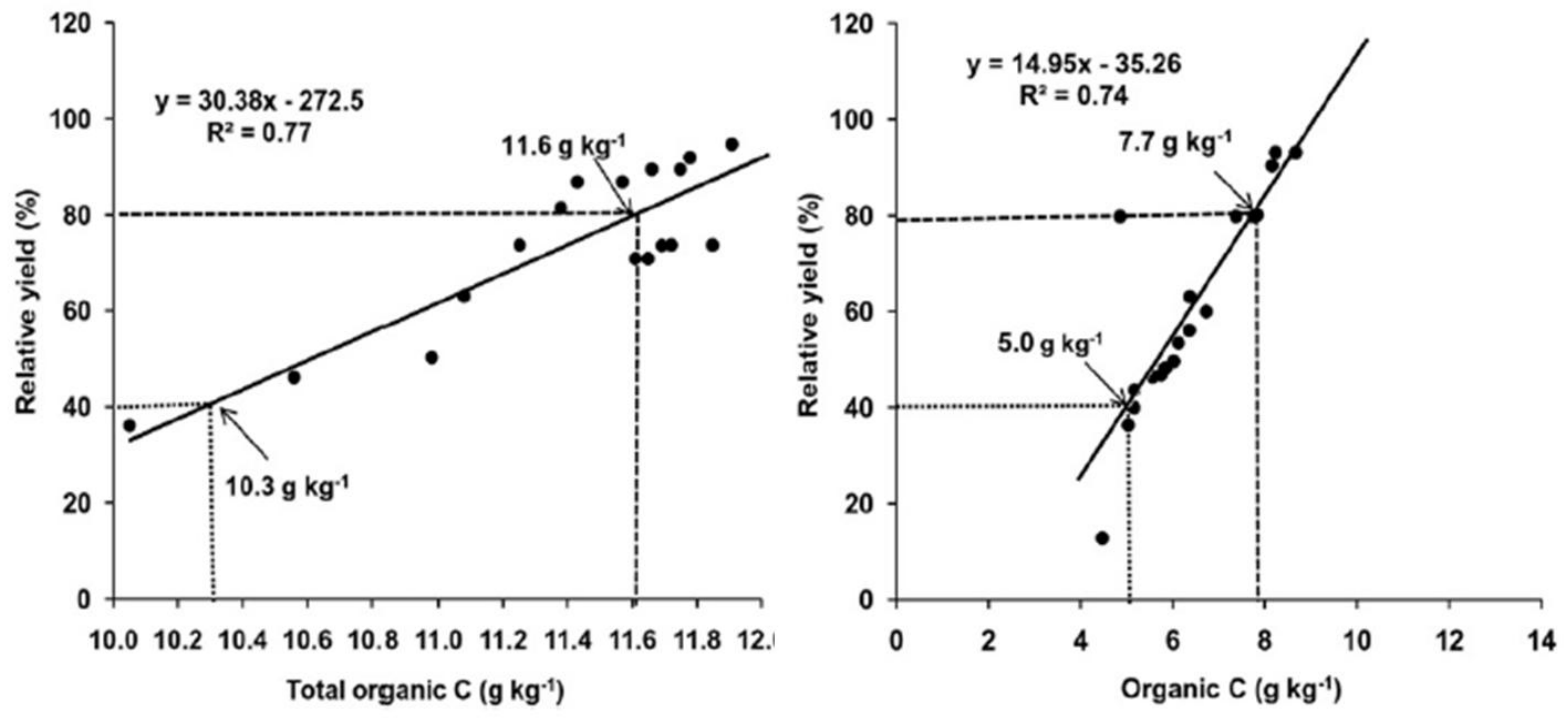

Fig.3 conceptual relationship between increasing fertilizer $\mathrm{N}$ rates, grain yield and agronomic efficiency in a) responsive soil, b) less responsive soil
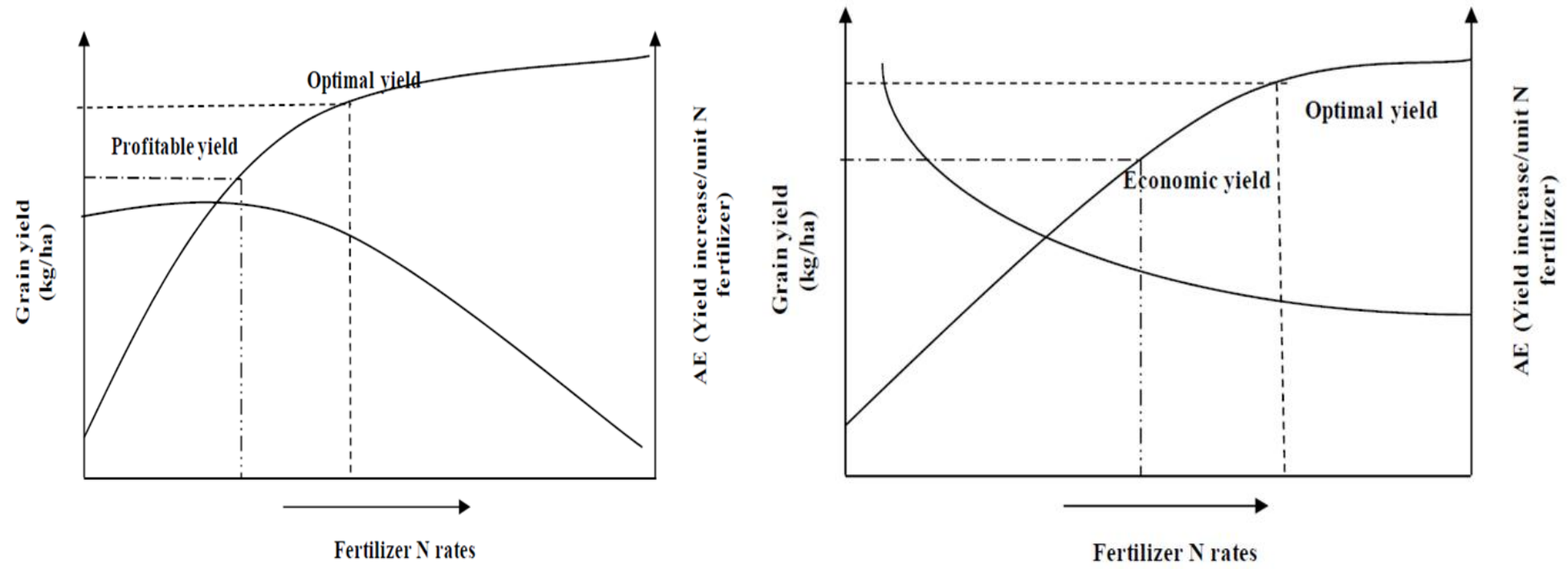
Soil organic carbon thresholds for crop response to applied nitrogen sources

Crop responses to added $\mathrm{N}$ fertilizer is a function of total $\mathrm{N}$ present (potentially mineralisable $\mathrm{N}$ ), crop $\mathrm{N}$ demand, and capacity of soil to hold $\mathrm{N}$ from losses due to leaching, erosion, volatilization. If soil properties and crop management aspects are ideal, crop response to added $\mathrm{N}$ fertilizer can be a function of SOC amount, but there must be a critical SOC range for minimum and highest yield response, and below which added fertilizer results in no response. Use of organic $\mathrm{N}$ fertilizer can be challenging in assessing crop response to its application. Organic fertilizer has diverse nutrient. The focus is on mineral fertilizer with particular focus on adding $\mathrm{N}$ fertilizers. Efforts to determine these SOC thresholds/critical ranges for some farming systems for nutrient management exists in some countries but remain dismal.

Mapfumo (2006) conducted a study in Zimbabwe on a sandy soil (Arenosol) with 120 fields categorized into three different rainfall zones using maize as the test crop. Very low and sometimes no response to added fertilizer was evident in fields having less than $4.6 \mathrm{~g} \mathrm{C} \mathrm{kg-1} \mathrm{SOC.}$

However, SOC values in a range 4.6 and $6.5 \mathrm{~g}$ C kg-1 (Mapfumo, 2006) resulted in high variations to fertilizer response. Yield increase in fields with SOC higher than $6.5 \mathrm{~g}$ $\mathrm{C}$ were also noted. Excessive use of organic related inputs, to as high as $20 \mathrm{t}$, did not enhance total SOC to more than $8.5 \mathrm{~g} \mathrm{C}$. This suggested that the application of organic matter in some farming systems does not always result in improved SOC content, and the sand particle sizes seem to have reached saturation points. Thus depending on the texture of the soil, SOC thresholds can vary depending on soil type.
A conceptual relationship between increasing fertilizer $\mathbf{N}$ rates, grain yield and agronomic efficiency

Musinguzi et al., (2013) made a hypothetical assessment, (Figures $3 \mathrm{a}$ and $3 \mathrm{~b}$ ) illustrating critical values with an optimum agronomic efficiency of added $\mathrm{N}$ and yield, for soils of different responsiveness (with SOC as a lead indicator). In the two figures, a less responsive soil is poor with minimum amounts of key soil quality indicators such as SOC. A responsive soil is a good field with basic qualities that lead to high responses to added N, with critical SOC levels. In a less responsive good soil (Figure 3b), high agronomic efficiency prevails at low $\mathrm{N}$ rates while optimum yield at high $\mathrm{N}$ application rates. This suggests that optimum $\mathrm{AE}$ is always below optimum yield, at the lowest $\mathrm{N}$ application rate. Nitrogen rates beyond optimum yield result in low agronomic efficiency and crop response. Economic profitability is achieved at intermediate $\mathrm{N}$ fertilizer rates. In a responsive soil, there is a strong correlation between yield and $\mathrm{N}$ application rates. Agronomic efficiency is high at the start and declines only at highest $\mathrm{N}$ application rates (Figure 3a). The conceptual diagrams suggest a need to aim at building SOC in responsive soils (Figure 3a) that require less $\mathrm{N}$ levels and can minimize the amount of reactive $\mathrm{N}$ in the environment. This implies that 'optimal yield' is not a necessity, but rather attaining a 'high yield' that results in high NUE and is environmentally sensitive, is most appropriate.

Up to this a brief account on the effects of SOC on various soil functions; role of SOC in getting a clear picture of crop productivity were briefly dealt with. The next case study that's shown here shows that considering only labile fraction of carbon doesn't give a clear picture of the yield estimation. 
In conclusion it is still difficult to establish a minimum or maximum SOC threshold value that can be universally or regionally accepted. The use of generalized SOC thresholds values for regulating added $\mathrm{N}$ application for all tropical soils remains a difficult option. Soil organic carbon can be taken as an affordable soil quality indicator. But fluxes of mineral $\mathrm{N}$ during crop growth should be integrated with SOC so as to get true reflection on productivity. Soil organic carbon threshold for sustaining soil quality is widely suggested to be about $2 \%$ in temperate region while $1.1 \%$ for tropical region soils. A critical limit of SOC in two soil orders in rice-rice cropping systems in Indo-gangetic plains was given; $1.03 \%-1.16 \%$ (entisol) and $0.5 \%$ $0.77 \%$ (alfisol). The structural stability of soil is affected below a threshold value of $2 \%$ SOC content. Minimum SOC thresholds can be identified for a given soil type, but maximum thresholds depend on crop $\mathrm{N}$ requirements, crop $\mathrm{N}$ use efficiency and amount of $\mathrm{N}$ applied.

\section{References}

Ackerman, F.G. and Myers, H.E. 1943. Some factors influencing aggregation in clay pan soils. Soil Sci., 55: 405-413.

Alves de Castro Lopes, A., Gomes de Sousa, D. M., Chaer, G.M., Bueno dos Reis Junior, F., Goedert, W.J., \& de Carvalho Mendes, I. 2013. Interpretation of microbial soil indicators as a function of crop yield and organic carbon. Soil Sci. Society of America J., 77(2): 461-472.

Baldock, J.A. and Skjemstad, J.O. 1999. Soil organic carbon/soil organic matter. In 'Soil Analysis: an Interpretation Manual, 159-170. CSIRO Publishing: Collingwood.

Biswas, S., Hazra, G.C., Purakayastha, T.J., Saha, N., Mitran, T., Roy, S.S., Basak, N., and Mandal, B. 2017. Establishment of critical limits of indicators and indices of soil quality in rice-rice cropping systems under different soil orders. Geoderma, 292: 34-48

Boix-Fayos, C., Calvo-Cases, A., Imeson, A. C., and Soriano-Soto, M.D. 2001. Influence of soil properties on the aggregation of some Mediterranean soils and the use of aggregate size and stability as land degradation indicators. Catena, 44: 47-67.

Boekel, P. 1963 The effect of organic matter on the structure of clay soils. Netherlands $J$. Agri. Sci., 11: 250-263.

Carter, M.R. 1992. Influence of reduced tillage systems on organic matter, microbial biomass, macro-aggregate distribution and structural stability of the surface soil in a humid climate. Soil \& Tillage Res., 23: 361-372.

Ekwue, E.I. 1990. Organic-matter effects on soil strength properties. Soil and Tillage Res., 16: 289-297.

Eshetu, Z., Giesler, R., and Högberg, P. 2004. Historical land use pattern affects the chemistry of forest soils in the Ethiopian highlands. Geoderma, 118: 149-165.

Gong, W., Yan, X.Y., Wang, J.Y., Hu, T. X., \&Gong, Y.B. 2009. Long-term manuring and fertilization effects on soil organic carbon pools under a wheat-maize cropping system in North China Plain. Plant and Soil, 314(1-2): 67-76.

Greenland, D.J., Rimmer, D. and Payne, D. 1975. Determination of the structural stability class of English and Welsh soils, using a water coherence test. J. Soil Sci., 26: 294-303.

Haynes, R.J., and Naidu, R. 1998. Influence of lime, fertiliser and manure applications on soil organic matter content and soil physical conditions: a review. Nutrient Cycling in Agroecosystems, 51: 123-137.

Haynes, R.J. 2000. Labile organic matter as an indicator of organic matter quality in arable and pastoral soils in New Zealand. Soil Biol. Biochem., 32: 211-219.

Janzen, H.H., Larney, F.J., and Olson, B.M. 1992. Soil quality factors of problem soils in Alberta. Proceedings of the Alberta Soil Science Workshop, 17-28. 
Lopes, A.A.C., Sousa, D.M.G., Chaer, G.M., Junior, F.B.R., Goedert, W.J. and Mendes, I.C. 2013. Interpretation of microbial soil indicators as a function of crop yield and organic carbon. Soil Sci. Soc. Am. J., 77: 461-472.

Loveland, P. and Webb, J. 2003. Is there a critical level of organic matter in the agricultural soils of temperate regions? A review. Soil \& Tillage Res., 70: 1-18.

Malinda, D.K. 1995. Factors in conservation farming that reduce erosion. Animal Production Sci., 35(7): 969-978.

Mapfumo, P. 2006. Defining soil organic carbon thresholds that could favour maize responses to mineral fertilizers on a granitic sandy soil (Arenosol. in Zimbabwe. The 18th World Congress of Soil Science (July 9-15, 2006). Philadelphia, Pennsylvania, USA.

Musinguzi, P., Tenywa, J.S., Ebanyat, P., Tenywa, M.M., Mubiru, D.N., Basamba, T.A., \& Leip, A. 2013. Soil organic carbon thresholds and nitrogen management in tropical agroecosystems: concepts and prospects.

Musinguzi, P., Ebanyat, P., Tenywa, J.S., Basamba, T.A., Tenywa, M.M., \& Mubiru, D.N. 2016. Critical Soil Organic carbon range for optimal crop response to mineral fertiliser nitrogen on a Ferralsol. Experimental Agriculture, 1-19.

Mondal, A.K., Rai, A.P., Wali, P. and Kumar, M. 2015. Available micronutrient status and their relationship with soil properties of vegetable growing area of Jammu district. Progressive Horticulture, 47(1): 95-98.

Musinguzi, P., Ebanyat, P., Tenywa, J.S., Basamba, T.A., Tenywa, M.M. and
Mubiru, D. 2015. Precision of farmerbased fertility ratings and soil organic carbon for crop production on a Ferralsol. Solid Earth, 6: 1063-1073.

Oades, J.M., Gillman, G.P., \&Uehara, G. 1989. Interactions of soil organic matter and variable-charge clays. Dynamics of soil organic matter in tropical ecosystems (6995). University of Hawaii Press: Honolulu.

Pieri, C. 1995. Land quality indicators. World Bank Discussion Paper 315. Washington, DC. The World Bank.

Prasad Datta, S., Kumar Rattan, R., and Chandra, S. 2010. Labile soil organic carbon, soil fertility, and crop productivity as influenced by manure and mineral fertilizers in the tropics. J. Plant Nutrition and Soil Sci., 173(5): 715-726.

Smith, A.J., \&Dumanski, J. 1993. FESLM: an international framework for evaluating sustainable landmanagement. American J. Alternative, World Soil Re-sources Report No. 73. Rome: FAO.

Ssali, H. 2000. Soil resources of Uganda and their relationship to major farming systems. Resource paper. Soils and Soil Fertility Management Programme, Kawanda, NARO, Uganda.

Stengel, P., Douglas, J.T., Guérif, J., Goss, M. J., Monnier, G., and Cannell, R.Q. 1984. Factors influencing the variation of some properties of soils in relation to their suitability for direct drilling. Soil \& Tillage Res., 4: 35-53.

Watts, C.W. and Dexter, A.R. 1997. The influence of organic matter in reducing the destabilization of soil by simulated tillage. Soil \& Tillage Res., 42: 253-275.

\section{How to cite this article:}

Atul Bhagawan Pawar, Chiranjeev Kumawat, Anil Kumar Verma, Ravi Kumar Meena, Md. Basit Raza, Ajin S Anil, Trivedi, V. K. 2017. Threshold Limits of Soil In Relation To Various Soil Functions and Crop Productivity. Int.J.Curr.Microbiol.App.Sci. 6(5): 2293-2302. doi: https://doi.org/10.20546/ijcmas.2017.605.256 